\title{
Chia Seed Addition to Cheese Bread Contributed to the Increase in the Omega-3 Fatty Acid Concentration without Changing the Physico-chemical and Sensory Characteristics
}

\author{
Alex Richard Costa Silva ${ }^{1, *}$, Izabelly Cavalcante Cavassani ${ }^{2}$, Ariane Dias de Amorim², Érica Aguiar Moraes ${ }^{2}$, \\ Erika Madeira Moreira da Silva ${ }^{1}$ \\ ${ }^{1}$ UFES, Federal University of Espirito Santo, Post-Graduation Program in Nutrition and Health (PPGNS), Center of Health Sciences, \\ Avenida Marechal Campos, 1468, Maruípe, Vitória-ES, Brazil \\ ${ }^{2}$ UFES, Federal University of Espirito Santo, Center of Health Sciences, Avenida Marechal Campos, 1468, Maruípe, Vitória-ES, Brazil \\ *Corresponding author: richard.ufes@gmail.com
}

\begin{abstract}
The objective of this study was to physico-chemically and sensorially characterize cheese breads prepared with different concentrations of chia seeds during storage. Cheese breads were prepared with chia seed concentrations of $5.0 \mathrm{~g} / 100 \mathrm{~g}$ (T5), $7.5 \mathrm{~g} / 100 \mathrm{~g}$ (T7) and $10.0 \mathrm{~g} / 100 \mathrm{~g}$ (T10). The preparations were physico-chemically and sensorially evaluated throughout the 90-day storage period. The T5 and T7 samples presented satisfactory physico-chemically characteristics and acceptances by the judging panel. The omega-3 fatty acid contents of the T5 and T7 samples were similar. The $\mathrm{pH}$ decreased during the 90 days of storage, and the acid level peaked after 60 days. The T7 sample was physically stable, and only its colour attribute changed during the storage period. The sample containing $7.5 \mathrm{~g} / 100 \mathrm{~g}$ of chia seeds, in addition to having satisfactory physico-chemically and sensorially characteristics during the 90 days, constituted an excellent source of omega-3 fatty acids.
\end{abstract}

Keywords: Salvia hispanica L., cheese bread, storage, omega-3 fatty acids, fatty acid

Cite This Article: Alex Richard Costa Silva, Izabelly Cavalcante Cavassani, Ariane Dias de Amorim, Érica Aguiar Moraes, and Erika Madeira Moreira da Silva, "Chia Seed Addition to Cheese Bread Contributed to the Increase in the Omega-3 Fatty Acid Concentration without Changing the Physico-chemical and Sensory Characteristics." Journal of Food and Nutrition Research, vol. 6, no. 6 (2018): 393-399. doi: 10.12691/jfnr-6-6-7.

\section{Introduction}

Coming from the cuisine of Minas Gerais (Brazil), cheese bread is considered a classic Brazilian dish and is a world-renowned bakery product. The consumption of cheese bread has become increasingly common due to the ease of production and public excitement about the product [1]. Because it is gluten-free, this product is a food option for those suffering from celiac disease [2].

The nutritional value and quality of bread products such as cheese bread, which are usually rich in refined carbohydrates and lipids, can be improved by the addition of seeds and/or whole flours to their recipes [3].

Chia (Salvia hispanica L.), a seed of Andean origin, has a high concentration of polyunsaturated fatty acids, including omega-3 fatty acids, proteins, dietary fibres and antioxidants $[4,5,6]$. These compounds, in addition to contributing to improved nutritional qualities of baked goods, have certain health benefits such as improving dyslipidaemia, glucose tolerance and insulin resistance and reducing inflammation and the risk of cardiovascular disease $[7,8,9]$.

However, in addition to the lipid-related benefits, the high content of polyunsaturated fatty acids present in chia seeds makes them more susceptible to peroxidation during storage, and it alters their oxidative stability and favours rancidification [10]. Therefore, the development of food with added chia seeds or flour is a major challenge for the industry, and the appearance, freshness, sensory qualities, and nutritional characteristics of the product as well as the required storage conditions must be considered [11].

In this perspective, the development of cheese loaves with a higher content of chia seeds seems to be one method for improving the nutritional quality of the product. However, the correct use of raw materials, as well as their concentration and handling during storage are essential for obtaining products with desirable sensory characteristics. Thus, the objective of the present study was to develop cheese breads with different concentrations of chia seeds and to evaluate their physical-chemical and sensorial characteristics before and during storage. 


\section{Materials and Methods}

\subsection{Raw Materials and Formulation of Cheese Breads}

The formulation used to prepare the cheese loaves was adapted from a study by Pereira et al. (2010) [12]. The amount of each ingredient was as follows: $39.37 \mathrm{~g} / 100 \mathrm{~g}$ of sour starch, $9.84 \mathrm{~g} / 100 \mathrm{~g}$ of egg, $15.75 \mathrm{~g} / 100 \mathrm{~g}$ of milk, $9.84 \mathrm{~g} / 100 \mathrm{~g}$ of soybean oil, $19.69 \mathrm{~g} / 100 \mathrm{~g}$ of ricotta, 3.94 $\mathrm{g} / 100 \mathrm{~g}$ of grated parmesan cheese and $1.57 \mathrm{~g} / 100 \mathrm{~g}$ of salt.

Appropriate chia seed concentrations were determined through preliminary tests, which allowed the selection of treatments that presented acceptable sensorial characteristics and took into consideration the correct proportions could increase the nutritional value in relation to dietary fibre and polyunsaturated fatty acid contents. Thus, the concentrations of $5.0 \mathrm{~g}$ chia/100 g mass (T5); $7.5 \mathrm{~g}$ chia/100 g mass (T7); and $10.0 \mathrm{~g}$ chia/100 g mass (T10) were selected, and these amounts of chia seeds were added to the standard formulation. The control sample was prepared without the addition of chia seeds (TC). Chia seeds were kindly provided by Vila Ervas ${ }^{\circledR}$ - Vila Velha/ES (Brazil).

The ingredients were weighed separately on a scale (Even-CT-6200AS-BI) with a maximum capacity of 6200 g (0.01 g). The sour starch and salt were mixed in a bowl. Milk and soybean oil were blanched at $95^{\circ} \mathrm{C}$ and added to the mixture. Ricotta, parmesan cheese and chia seeds were added to the mixture and dissolved to obtain a homogeneous mass. The cheese loaves were manually moulded in cylindrical forms (20 g) and cooked at $180^{\circ} \mathrm{C}$ in an industrial oven for 20 minutes.

\subsection{Physical Characterization}

The weight of each bread sample before and after baking was determined using a precision scale with a maximum capacity of $6200 \mathrm{~g}$ (0.01 g). The apparent volume (AV) was determined by the millet seed displacement method in a graduated beaker $(\mathrm{mL})$. The specific volume (SV) was calculated from the ratio between the volume of the cheese bread and its weight ( $\mathrm{mL} / \mathrm{g}$ ) according to the method described by Pizzinatto et al. (1993) [13]. The density (D) was calculated according to the formula mass $(\mathrm{g}) /$ volume $(\mathrm{mL})$. The coefficient of expansion (EC) was calculated using the following formula: volume of the cheese bread (mL) - volume of the raw mass $(\mathrm{mL}) /$ volume of the raw mass $(\mathrm{mL}) \times 100$, and the result is expressed as a percentage (\%). The yield (R) was determined by the following formula: weight (g) of the processed cheese bread/weight (g) of the raw cheese bread $\mathrm{x} 100$, and the result is expressed as a percentage (\%).

\subsection{Order-preference Test}

The samples of cheese bread with chia were submitted to order-preference tests in which the judges were instructed to rank the samples in order of their preference [14]. A group of eleven untrained judges, comprising students and staff from the Federal University of Espírito Santo (UFES, Brazil), were invited to participate in the test. The participants received the samples in a monadic and randomized fashion, and the samples were coded with three random digits and accompanied by mineral water. The tests were conducted in individual, tailored cubicles under white lighting. The participation of the judges was preceded by their voluntary signature of the Term of Free and Informed Consent. The present study was approved by the Research Ethics Committee of the Health Sciences Center of the Federal University of Espírito Santo (CAAE: 44893015.5.0000.5060; Protocol No. 1.171.574/2015). Participants under 18 years of age and those who reported to dislike cheese loaves were excluded. The sensorial analysis was conducted in the Laboratory of Dietetic Technique of the Health Sciences Center of UFES.

\subsection{Chemical Characterization}

After baking, the cheese loaves were ground by hand to obtain homogeneous samples.

The centesimal composition was determined in triplicate according to the methodology proposed by the Association of Official Analytical Chemistry [15]. Ash was determined using a muffle incinerator at $550^{\circ} \mathrm{C}$. Crude nitrogen was measured by the Kjeldahl method and converted to crude protein by a factor of 6.25. The lipid content was determined by Soxhlet extraction using petroleum ether as the solvent. Moisture analysis was performed by oven drying the bread at $105^{\circ} \mathrm{C}$ for 6 hours. Available carbohydrates were calculated by difference according to the following formula: 100 (g) - ((moisture) (g) + proteins (g) + lipids (g) + ashes (g)). The calorie content (kcal) of the cheese loaves was estimated considering the Atwater conversion factors, which are 4 $\mathrm{kcal} / \mathrm{g}$ of proteins, $4 \mathrm{kcal} / \mathrm{g}$ of carbohydrates and $9 \mathrm{kcal} / \mathrm{g}$ of lipids [16].

The $\mathrm{pH}$ was determined using a microprocessed benchtop digital pH meter (Tecnopon ${ }^{\circledR}$ mPA-210), and titratable total acidity (TTA) was determined using $0.1 \mathrm{~N}$ sodium hydroxide and phenolphthalein [15]. All analyses were performed in triplicate.

\subsubsection{Profile of Fatty Acids}

The lipid fraction of each sample was extracted by the method described by Folch et al. (1957) [17]. The samples were then saponified in $2.0 \mathrm{~mL}$ of methanol solution $(0.5 \mathrm{~mol} / \mathrm{L})$ for $25 \mathrm{~min}$ in a $75-80^{\circ} \mathrm{C}$ bath followed by methylation according to the method described by Hartman and Lago (1973) [18]. The fatty acid profile was determined on a Solution SHIMADZU® gas chromatograph equipped with a flame ionization detector (FID). To record and analyse the chromatograms, the apparatus was coupled to a microcomputer with the GC Solution program. Compounds were separated and identified on a Carbowax capillary column (30 m x 0.25 $\mathrm{mm})$. For the chromatographic separation, $1 \mathrm{~mL}$ of sample was injected using a $10-\mathrm{mL}$ syringe (Hamilton ${ }^{\circledR}$ ) with a split of 10 . Nitrogen gas was used as the carrier with a linear velocity of $43.2 \mathrm{~cm} / \mathrm{s}$, and hydrogen and synthetic air formed the flame in the detector [19]. 


\subsection{Storage}

The samples used for storage analysis were selected based on the results of the physico-chemically characterization and the order-preference tests. The cheese loaf samples were transferred to low-density polyethylene bags, sealed with a pedal sealer (Sulpack ${ }^{\circledR}$ - SP400T) and frozen in a vertical freezer at $-25^{\circ} \mathrm{C}$ until analysis. The cheese loaves were analysed after baking on the day of preparation (01), and dough samples were thawed and subsequently baked after 30, 60 and 90 days of storage. The control sample was only used in physico-chemically characterization.

The physical characterization of the cheese loaves was conducted as described in item 2.2. The sensorial analysis on days $01,30,60$ and 90 was performed by 40 untrained judges using a 9 - point hedonic acceptability scale (9 - I liked it very much, 5 - I did not like it or I did not dislike it and 1 - I disliked it very much) according to Minim (2013) [14]. The attributes of colour, aroma, flavour and texture were evaluated. The cheese breads with chia were considered to be accepted when the acceptability scores for the attribute were greater than or equal to six (I liked slightly) [20]. The control sample was not considered so it would not influence the judge's perception of the samples containing chia, since acceptability analysis also includes preference. The test conditions are described in item 2.3. The analysis of moisture, $\mathrm{pH}$ and TTA were conducted as described in item 2.4 .

\subsection{Statistical Analyses}

The result of the order-preference test was analysed using the Friedman test and using the Newell and MacFarlane table [21]. Differences between the sums of the orders that were greater than or equal to the critical value 26 indicated that there was a difference between the samples at $5 \%$ probability. For the physical, chemical and acceptability tests, one-way ANOVA was used followed by the comparison of the means by using Tukey's test at $5 \%$ of probability using Statistica software version 10.0.

\section{Results and Discussion}

\subsection{Physical Characterization}

The cheese loaves with higher concentrations of chia had the lowest apparent and specific volumes. It should be noted that the T5 sample presented values closer to the control sample (Table 1). The T5 and T10 samples were denser and had lower coefficients of expansion that those of CT (Table 1). In general, the increase in chia concentration resulted in cheese loaves with lower volumes, expansion coefficients, yields, and, consequently, higher densities. The reduction in volume and the lower coefficients of expansion can be explained by the presence of fibres and omega-3 fatty acids, respectively. According to Katina et al. (2006) [22], the addition of fibres to a bakery product weakens its structure, which will reduce the elasticity and volume of the crumb. Aplevicz and Demaiate (2007) [23] evaluated the addition of okara by-product (soybean residue), which is rich in dietary fibre, in the proportions of 5.0, 10.0, $15.0 \mathrm{~g} / 100 \mathrm{~g}$ relative to the starch in cheese breads and concluded that cheese breads produced with $15.0 \mathrm{~g} / 100 \mathrm{~g}$ of okara had lower volumes and expansions. Additionally, Oliveira and Moraes (2009) [1] produced cheese loaves enriched with omega-3 fatty acids in concentrations of $1.0 \mathrm{~g} / 100 \mathrm{~g}$ and $3.0 \mathrm{~g} / 100 \mathrm{~g}$ and, and they found that cheese loaves with $3.0 \mathrm{~g} / 100 \mathrm{~g}$ omega-3 fatty acids had lower coefficients of expansion, but when the concentration was changed to 1.0 $\mathrm{g} / 100 \mathrm{~g}$, the obtained products showed little growth, they were compact and hard, and had gummy consistencies.

\subsection{Order-preference Test}

The sample with highest content of chia (T10) was least preferred because it had a residual fish taste compared with the T5 sample. The T5 and T10 samples were similar to the T7 treatment of chia (Table 1). Costa et al. (2012) [24] evaluated the addition of flax meal, which is a source of dietary fibre and omega-3 fatty acids, to cheese breads in proportions of 1.0, 5.0 and $10.0 \mathrm{~g} / 100 \mathrm{~g}$ using a sensorial 9-point hedonic scale, which corroborates the results found in the present study.

\subsection{Chemical Characterization}

Samples containing chia seeds showed higher levels of moisture (Table 2). The elevation of moisture may be related to the fact that chia seeds have the capacity to retain and absorb water due to their soluble fibre content [25]. The same result was observed by Pereira et al. (2013) [26] who found that the moisture values in potato breads with added chia flour were higher than those prepared without chia flour.

The $\mathrm{pH}$ values were lower in samples containing chia (Table 2). This fact can be explained due to the content of polyunsaturated fatty acids present in the seeds. Unsaturated fatty acids when subjected to, for example, heat treatment, are oxidized and release acids, aldehydes, ketones, alcohols and hydrocarbons [27]. These compounds may reduce the $\mathrm{pH}$ of the product, and this result is consistent with what was observed by Oliveira and Moraes (2009) [1].

The addition of chia seeds to cheese breads reduced the ratios of polyunsaturated fatty acids (PUFA): saturated (SAT) and linoleic acid (C18:1 - $\omega-6)$ : alpha linolenic acid (C18:3 - $\omega$-3) (Table 2). The reduction in the PUFA: SAT ratio may have been influenced by the amount of soybean oil used in the preparation (25 g/100 g), which is the source of linoleic acid. According to Sacks et al. (2017) [9], the concentration of linoleic acid in the soybean oil is approximately $50.0 \mathrm{~g} / 100 \mathrm{~g}$. It is possible that the content of this fatty acid in the oil is the dominant factor instead the fatty acid contribution from the chia seeds.

The increase in the amounts of eicosapentaenoic acid (EPA) (C20:5 - $\omega-3$ ) and alpha linolenic acid in the samples containing chia seeds were significant when compared to the control sample. The recommended daily value of alpha linolenic acid for healthy individuals is $\sim 1$ g/day [28]. Cheese bread can account for between $29 \%$ and $53 \%$ of this recommendation. According to the classification proposed by Philippi (2014) [29], cheese breads can be considered an excellent source $(>20 \%)$ of 
this fatty acid. Therefore, the consumption of six cheese loaves ( 100 g each) containing $7.5 \mathrm{~g} / 100 \mathrm{~g}$ chia seeds corresponds to two servings of carbohydrates and may contribute $50 \%$ of the daily recommended dose of alpha linolenic acid.

Thus, considering the physical-chemical results and the preferences of the judges, the T5 and T7 samples were examined in the storage stage.

Table 1. Physical characterization and preference analyses of chia seed cheese breads

\begin{tabular}{lcccc}
\hline & & Treatments & \\
& TC & T5 & T7 & T10 \\
\hline & & Physical characteristics & \\
AV $(\mathrm{mL})$ & $185 \pm 21.21^{\mathrm{a}}$ & $165 \pm 7.07^{\mathrm{ab}}$ & $120 \pm 0.00^{\mathrm{bc}}$ & $110 \pm 0.00^{\mathrm{c}}$ \\
$\mathrm{SV}(\mathrm{mL} / \mathrm{g})$ & $2.80 \pm 0.34^{\mathrm{a}}$ & $2.47 \pm 0.11^{\mathrm{a}}$ & $1.73 \pm 0.00^{\mathrm{b}}$ & $1.63 \pm 0.02^{\mathrm{b}}$ \\
$\mathrm{D}(\mathrm{g} / \mathrm{mL})$ & $0.35 \pm 0.04^{\mathrm{b}}$ & $0.40 \pm 0.02^{\mathrm{b}}$ & $0.57 \pm 0.00^{\mathrm{a}}$ & $0.61 \pm 0.01^{\mathrm{a}}$ \\
EC $(\%)$ & $208.33 \pm 35.36^{\mathrm{a}}$ & $135.71 \pm 10.10^{\mathrm{ab}}$ & $85.71 \pm 20.20^{\mathrm{b}}$ & $101.66 \pm 25.93^{\mathrm{b}}$ \\
R $(\%)$ & $85.02 \pm 0.75^{\mathrm{ab}}$ & $83.70 \pm 2.61^{\mathrm{ab}}$ & $86.03 \pm 0.70^{\mathrm{a}}$ & $82.99 \pm 0.14^{\mathrm{b}}$ \\
& & Order-preference test & & $121^{\mathrm{ab}}$ \\
Sum of orders & - & $109^{\mathrm{a}}$ & $136^{\mathrm{b}}$ \\
\hline
\end{tabular}

$\mathrm{TC}=$ control sample (without chia); $\mathrm{T} 5=$ sample with $5.0 \mathrm{~g} / 100 \mathrm{~g}$ of chia seeds; $\mathrm{T} 7=$ sample with $7.5 \mathrm{~g} / 100 \mathrm{~g}$ of chia seeds; T10 = sample with 10.0 $\mathrm{g} / 100 \mathrm{~g}$ of chia seeds. AV = Apparent volume; $\mathrm{SV}=$ Specific volume; $\mathrm{D}=$ Density; $\mathrm{EC}=$ Expansion coefficient; $\mathrm{R}=$ Yield. The results are expressed as the means \pm standard deviation. Same letters in the same line indicate the results are not different by Tukey's test $(\mathrm{p}<0.05)$. Order-preference test: least significant difference (LSD): 26. Number of judges: 61 . Sums of orders with the same letter do not differ from each other according to the Friedman test $(\mathrm{p}<0.05)$.

Table 2. Chemical characterization of chia seed cheese breads.

\begin{tabular}{|c|c|c|c|c|}
\hline & \multicolumn{4}{|c|}{ Treatments } \\
\hline & TC & T5 & $\mathrm{T} 7$ & $\mathrm{~T} 10$ \\
\hline \multicolumn{5}{|c|}{ Chemical composition (g/100 g) and caloric value (kcal/100 g) } \\
\hline Moisture & $24.23 \pm 1.07^{\mathrm{b}}$ & $28.31 \pm 0.37^{\mathrm{a}}$ & $28.57 \pm 0.57^{\mathrm{a}}$ & $26.25 \pm 0.90^{\mathrm{a}}$ \\
\hline Ash & $3.60 \pm 0.59^{\mathrm{a}}$ & $3.45 \pm 0.23^{\mathrm{a}}$ & $4.25 \pm 0.13^{\mathrm{a}}$ & $3.81 \pm 0.27^{\mathrm{a}}$ \\
\hline Protein & $10.05 \pm 1.61^{\mathrm{a}}$ & $11.67 \pm 1.44^{\mathrm{a}}$ & $12.15 \pm 0.88^{\mathrm{a}}$ & $12.52 \pm 1.40^{\mathrm{a}}$ \\
\hline Lipids & $11.84 \pm 0.67^{\mathrm{a}}$ & $13.50 \pm 0.70^{\mathrm{a}}$ & $14.01 \pm 0.59^{\mathrm{a}}$ & $14.88 \pm 4.26^{\mathrm{a}}$ \\
\hline Other carbohydrates & $48.93 \pm 1.50^{\mathrm{a}}$ & $41.15 \pm 1.40^{\mathrm{ab}}$ & $38.58 \pm 0.30^{\mathrm{b}}$ & $40.80 \pm 4.00^{\mathrm{ab}}$ \\
\hline Caloric value & $337.40 \pm 0.03^{\mathrm{a}}$ & $331.46 \pm 2.21^{\mathrm{a}}$ & $326.21 \pm 3.50^{\mathrm{a}}$ & $351.71 \pm 22.30^{\mathrm{a}}$ \\
\hline $\mathrm{pH}$ & $6.10 \pm 0.07^{\mathrm{a}}$ & $5.94 \pm 0.06^{\mathrm{ab}}$ & $5.84 \pm 0.01^{\mathrm{b}}$ & $5.83 \pm 0.00^{\mathrm{b}}$ \\
\hline TTA & $2.75 \pm 0.14^{\mathrm{a}}$ & $2.46 \pm 0.27^{\mathrm{a}}$ & $2.65 \pm 0.27^{\mathrm{a}}$ & $2.65 \pm 0.00^{\mathrm{a}}$ \\
\hline \multicolumn{5}{|c|}{ Profile of fatty acids (g/100 g) } \\
\hline Saturated fat & $45.68 \pm 0.89^{\mathrm{a}}$ & $33.94 \pm 0.22^{\mathrm{C}}$ & $39.30 \pm 0.04^{\mathrm{b}}$ & $41 \pm 0.42^{b}$ \\
\hline Caprylic acid (C8:0) & $0.06 \pm 0.01^{\mathrm{a}}$ & $0.04 \pm 0.01^{\mathrm{a}}$ & $0.05 \pm 0.01^{\mathrm{a}}$ & $0.06 \pm 0.00^{\mathrm{a}}$ \\
\hline Capric acid (C10:0) & $0.85 \pm 0.05^{\mathrm{a}}$ & $0.51 \pm 0.01^{\mathrm{c}}$ & $0.53 \pm 0.03^{\mathrm{bc}}$ & $0.68 \pm 0.00^{\mathrm{ab}}$ \\
\hline Tridecyl acid (C13:0) & $3.30 \pm 0.20^{\mathrm{a}}$ & $2.47 \pm 0.00^{\mathrm{b}}$ & $2.74 \pm 0.04^{\mathrm{ab}}$ & $3.02 \pm 0.02^{\mathrm{ab}}$ \\
\hline Myristic acid (C14:0) & $0.19 \pm 0.01^{\mathrm{a}}$ & $0.18 \pm 0.01^{\mathrm{a}}$ & $0.19 \pm 0.01^{\mathrm{a}}$ & $0.23 \pm 0.03^{\mathrm{a}}$ \\
\hline Pentadecylic acid (C15:0) & $0.85 \pm 0.05^{\mathrm{a}}$ & $0.30 \pm 0.01^{\mathrm{b}}$ & $0.32 \pm 0.02^{\mathrm{b}}$ & $0.38 \pm 0.05^{\mathrm{b}}$ \\
\hline Palmitic acid (C16:0) & $28.85 \pm 0.15^{\mathrm{a}}$ & $21.83 \pm 0.04^{\mathrm{c}}$ & $25.91 \pm 0.09^{b}$ & $26.61 \pm 0.39^{b}$ \\
\hline Marginic acid (C17:0) & $0.40 \pm 0.00^{\mathrm{a}}$ & $0.32 \pm 0.01^{\mathrm{a}}$ & $0.32 \pm 0.03^{\mathrm{a}}$ & $0.44 \pm 0.06^{\mathrm{a}}$ \\
\hline Stearic acid (C18:0) & $10.57 \pm 0.43^{\mathrm{a}}$ & $7.75 \pm 0.25^{b}$ & $8.73 \pm 0.03^{b}$ & $9.03 \pm 0.03^{\mathrm{b}}$ \\
\hline Arachidic acid (C20:0) & $0.60 \pm 0.00^{\mathrm{a}}$ & $0.50 \pm 0.00^{\mathrm{b}}$ & $0.50 \pm 0.00^{\mathrm{b}}$ & $0.52 \pm 0.03^{b}$ \\
\hline Monounsaturated fat & $35.60 \pm 0.29^{\mathrm{a}}$ & $31 \pm 0.13^{b}$ & $32.59 \pm 0.51^{\mathrm{b}}$ & $31.30 \pm 0.26^{\mathrm{b}}$ \\
\hline Myristoleic acid (C14:1) & $0.13 \pm 0.04^{\mathrm{a}}$ & $0.15 \pm 0.01^{\mathrm{a}}$ & $0.07 \pm 0.00^{\mathrm{a}}$ & $0.05 \pm 0.02^{\mathrm{a}}$ \\
\hline Cis-10-pentadecenoic acid (C15:1) & $0.15 \pm 0.05^{\mathrm{a}}$ & $0.07 \pm 0.01^{\mathrm{a}}$ & $0.09 \pm 0.01^{\mathrm{a}}$ & $0.10 \pm 0.00^{\mathrm{a}}$ \\
\hline Palmitoleic acid (C16:1) & $0.70 \pm 0.00^{\mathrm{a}}$ & $0.66 \pm 0.01^{\mathrm{b}}$ & $0.61 \pm 0.01^{\mathrm{c}}$ & $0.14 \pm 0.00^{\mathrm{d}}$ \\
\hline Cis-10-heptadecenoic acid (C17:1) & $0.11 \pm 0.00^{\mathrm{a}}$ & $0.12 \pm 0.01^{\mathrm{a}}$ & $0.11 \pm 0.01^{\mathrm{a}}$ & $0.11 \pm 0.01^{\mathrm{a}}$ \\
\hline Oleic acid (C18:1 - $\omega-9)$ & $32.23 \pm 0.23^{\mathrm{a}}$ & $29.89 \pm 0.11^{\mathrm{b}}$ & $31.50 \pm 0.50^{\mathrm{ab}}$ & $29.80 \pm 0.20^{\mathrm{b}}$ \\
\hline Gondoico acid (C20:1 - $\omega-9)$ & $2.27 \pm 0.07^{\mathrm{a}}$ & $0.09 \pm 0.01^{\mathrm{c}}$ & $0.20 \pm 0.00^{\mathrm{c}}$ & $1.05 \pm 0.05^{\mathrm{b}}$ \\
\hline Polyunsaturated fat & $32.58 \pm 0.06^{\mathrm{a}}$ & $21.78 \pm 0.02^{\mathrm{c}}$ & $23.45 \pm 0.14^{\mathrm{b}}$ & $17.40 \pm 0.00^{\mathrm{d}}$ \\
\hline Linoleic acid (C18:1 - $\omega-6)$ & $29.55 \pm 0.05^{\mathrm{a}}$ & $17.88 \pm 0.12^{\mathrm{b}}$ & $17.90 \pm 0.11^{\mathrm{b}}$ & $13,84 \pm 0.03^{\mathrm{c}}$ \\
\hline Gamma linolenic acid (C18:3 - $\omega-6)$ & $2.86 \pm 0.01^{\mathrm{bc}}$ & $2.73 \pm 0.10^{c}$ & $3.10 \pm 0.05^{\mathrm{b}}$ & $4.95 \pm 0.03^{\mathrm{a}}$ \\
\hline Alpha linolenic acid (C18:3 - $\omega-3)$ & $0.60 \pm 0.01^{\mathrm{a}}$ & $0.29 \pm 0.00^{c}$ & $0.50 \pm 0.03^{b}$ & $0.53 \pm 0.01^{\mathrm{ab}}$ \\
\hline Eicosapentaenoic acid (EPA) (C20:5 - $\omega-3)$ & $0.10 \pm 0.01^{\mathrm{b}}$ & $0.20 \pm 0.10^{\mathrm{ab}}$ & $0.30 \pm 0.00^{\mathrm{a}}$ & $0.07 \pm 0.01^{\mathrm{b}}$ \\
\hline Ratio PUFA:SAT & 0.71 & 0.64 & 0.59 & 0.42 \\
\hline Ratio $\omega-6: \omega-3$ & 98.50 & 35.76 & 33.77 & 22.68 \\
\hline
\end{tabular}

TC = control sample (without chia); T5 = sample with $5.0 \mathrm{~g} / 100 \mathrm{~g}$ of chia seeds; $\mathrm{T} 7$ = sample with $7.5 \mathrm{~g} / 100 \mathrm{~g}$ of chia seeds; T10 = sample with 10.0 $\mathrm{g} / 100 \mathrm{~g}$ of chia seeds; TTA = Total Titratable Acidity. The results are expressed as the means \pm standard deviation. Same letters in the same line indicate the results do not differ by Tukey's test $(\mathrm{p}<0.05)$. 


\subsection{Storage}

After 90 days of storage, the expansion coefficients of TC and T5 samples had decreased (Table 3). In the T5 sample, the greatest changes in the analysed characteristics (except yield) occurred prior to the 30th day of storage. Therefore, in 30 days of storage, cheese loaves with $5.0 \mathrm{~g} / 100 \mathrm{~g}$ of chia seeds presented noticeably smaller volumes and lower expansion coefficients and were more compact after baking. Changing the parameters reinforces the explanation given by Katina et al. (2006) [22], who attributed the observation to the high fibre content in chia seeds. Stoll et al. (2015) [30], when making bread with wheat flour using orange fibre as a substitute for fat and with $\alpha$-amylase enzyme, report that the formulations with the highest fibre percentages showed the lowest specific volumes.

The physical parameters of the T7 sample remained stable during the 90 days of storage. Stability is associated with the amount of chia seeds present in the formulation and, consequently, the amount of dietary fibre. Chia seeds have a high water retention capacity due to their high fibre content, which contributes to the stability of physical parameters [31].

During storage, the moisture content of the control sample increase up to the 30th day (Table 4). After this period, the value remained constant. On the other hand, the moisture content of the T5 sample decreased and that of the T7 sample remained constant during the 90 days of storage. Freezing and storage of the dough for 90 days may have caused deleterious effects on the defrosted dough and therefore on the baked cheese bread. According to Phimolsiripol et al. (2008) [32] temperature fluctuations during freezing, for example, may cause increased rates of deterioration in the quality of the bakery product. Specifically, this may occur due to the formation of ice crystals and recrystallization. In addition, there may be an increase in moisture loss after cooking that would lead to a reduction in quality, which corroborates the findings of this study. The moisture stability in the T7 sample is related to the amount of dietary fibre, since chia seeds have a high water retention capacity due to their high fibre content [31].

The $\mathrm{pH}$ of all the samples decreased throughout the storage period, and a maximum value of acidity (3.02 $\mathrm{g} / 100 \mathrm{~g}$ ) was reached on the 60th day of storage in the T5 sample. The decrease in $\mathrm{pH}$ in the loaves prepared with chia seeds may be related to the oxidation of fatty acids during storage. The fatty acids can become rancid, which releases acids that reduce the $\mathrm{pH}$ and increase the acidity during freezing [10]. A reduction in $\mathrm{pH}$ was also found by Silva et al. (2009) [33] who evaluated cheese loaves stored at $-18^{\circ} \mathrm{C}$ for 120 days.

Aplevicz and Demaiate (2007) [23] noted that cheese breads do not have standardized manufacturing, characterization or typing technology. Manufacturers, in search of a better quality and lower cost product make changes to the formulations. The lack of standardization in the preparation of this product helps explain the differences between the results of previous reports and those of the present study.

The stored cheese breads prepared with chia seeds showed good acceptance scores (score $\leq 6$ ) among consumers for their aroma ( $\mathrm{T} 5=85 \%$ and $\mathrm{T} 7=81 \%$ ), flavour ( $\mathrm{T} 5=96 \%$ and $\mathrm{T} 7=96 \%$ ) and texture attributes (T5 $=89 \%$ and $\mathrm{T} 7=93 \%$ ) during the 90 days of storage. However, the colour attribute for the T7 sample showed negative oscillations throughout storage (Table 5). These oscillations may be related to the amount of chia seeds present in this treatment which are associated with the appearance of the samples and result in darker stained cheese breads. Corroborating this result, Moraes et al. (2010) [34] also showed dark staining and less cake acceptance when cakes were prepared with higher concentrations of flax meal (45\%).

Table 3. Physical characterization during storage for 90 days

\begin{tabular}{|c|c|c|c|c|c|}
\hline \multirow{2}{*}{ Treatments } & \multirow{2}{*}{ Parameters } & \multicolumn{4}{|c|}{ Storage time (days) } \\
\hline & & 01 & 30 & 60 & 90 \\
\hline \multirow{5}{*}{ TC } & $\mathrm{AV}(\mathrm{mL})$ & $185 \pm 21.21^{\mathrm{a}}$ & $145 \pm 21.21^{\mathrm{a}}$ & $150 \pm 0.00^{\mathrm{a}}$ & $125 \pm 7.07^{\mathrm{a}}$ \\
\hline & $\mathrm{SV}$ (mL/g) & $2.80 \pm 0.34^{\mathrm{a}}$ & $2.13 \pm 0.34^{\mathrm{a}}$ & $2.21 \pm 0.04^{\mathrm{a}}$ & $1.88 \pm 0.10^{\mathrm{a}}$ \\
\hline & $\mathrm{D}(\mathrm{g} / \mathrm{mL})$ & $0.35 \pm 0.04^{\mathrm{a}}$ & $0.47 \pm 0.08^{\mathrm{a}}$ & $0.45 \pm 0.01^{\mathrm{a}}$ & $0.53 \pm 0.03^{\mathrm{a}}$ \\
\hline & EC (\%) & $208.33 \pm 35.30^{\mathrm{a}}$ & $144.28 \pm 22.22^{\mathrm{ab}}$ & $77.08 \pm 14.70^{\mathrm{b}}$ & $66.96 \pm 6.31^{\mathrm{b}}$ \\
\hline & R (\%) & $85.02 \pm 0.75^{\mathrm{ab}}$ & $84.34 \pm 0.73^{\mathrm{ab}}$ & $86.52 \pm 1.63^{\mathrm{a}}$ & $82.86 \pm 1.26^{\mathrm{b}}$ \\
\hline \multirow{5}{*}{ T5 } & $\mathrm{AV}(\mathrm{mL})$ & $165 \pm 7.07^{\mathrm{a}}$ & $105 \pm 7.07^{\mathrm{b}}$ & $120 \pm 0.00^{\mathrm{ab}}$ & $135 \pm 21.21^{\mathrm{ab}}$ \\
\hline & $\mathrm{SV}(\mathrm{mL} / \mathrm{g})$ & $2.47 \pm 0.11^{\mathrm{a}}$ & $1.53 \pm 0.11^{\mathrm{b}}$ & $1.74 \pm 0.02^{\mathrm{b}}$ & $1.90 \pm 0.32^{\mathrm{ab}}$ \\
\hline & $\mathrm{D}(\mathrm{g} / \mathrm{mL})$ & $0.40 \pm 0.02^{\mathrm{b}}$ & $0.65 \pm 0.05^{\mathrm{a}}$ & $0.57 \pm 0.01^{\mathrm{ab}}$ & $0.53 \pm 0.09^{\mathrm{ab}}$ \\
\hline & EC (\%) & $135.71 \pm 10.10^{\mathrm{a}}$ & $61.90 \pm 6.73^{\mathrm{b}}$ & $41.66 \pm 11.79^{b}$ & $79.46 \pm 11.36^{\mathrm{b}}$ \\
\hline & R (\%) & $83.70 \pm 2.61^{b}$ & $85.89 \pm 1.93^{\mathrm{ab}}$ & $86.28 \pm 0.81^{\mathrm{ab}}$ & $88.63 \pm 1.06^{\mathrm{a}}$ \\
\hline \multirow{5}{*}{$\mathrm{T} 7$} & $\mathrm{AV}(\mathrm{mL})$ & $120 \pm 0.00^{\mathrm{a}}$ & $125 \pm 7.07^{\mathrm{a}}$ & $130 \pm 0.00^{\mathrm{a}}$ & $125 \pm 7.07^{\mathrm{a}}$ \\
\hline & $\mathrm{SV}(\mathrm{mL} / \mathrm{g})$ & $1.73 \pm 0.00^{\mathrm{a}}$ & $1.80 \pm 0.06^{\mathrm{a}}$ & $1.84 \pm 0.06^{\mathrm{a}}$ & $1.76 \pm 0.12^{\mathrm{a}}$ \\
\hline & $\mathrm{D}(\mathrm{g} / \mathrm{mL})$ & $0.57 \pm 0.00^{\mathrm{a}}$ & $0.55 \pm 0.02^{\mathrm{a}}$ & $0.54 \pm 0.02^{\mathrm{a}}$ & $0.56 \pm 0.04^{\mathrm{a}}$ \\
\hline & $\mathrm{EC}(\%)$ & $85.71 \pm 20.20^{\mathrm{a}}$ & $78.57 \pm 10.10^{\mathrm{a}}$ & $44.44 \pm 0.00^{\mathrm{a}}$ & $78.57 \pm 10.10^{\mathrm{a}}$ \\
\hline & R (\%) & $86.03 \pm 0.70^{\mathrm{a}}$ & $87.05 \pm 2.35^{\mathrm{a}}$ & $85.53 \pm 0.77^{\mathrm{a}}$ & $86.60 \pm 2.20^{\mathrm{a}}$ \\
\hline
\end{tabular}

$\mathrm{TC}=$ control sample (without chia); T5 = sample with $5.0 \mathrm{~g} / 100 \mathrm{~g}$ of chia seeds; $\mathrm{T} 7$ = sample with $7.5 \mathrm{~g} / 100 \mathrm{~g}$ of chia seeds. AV = Apparent volume; SV = Specific volume; D = Density; EC = Expansion coefficient; R = Yield. The results are expressed as the means \pm standard deviation. Same letters in the same line indicate the values do not differ by Tukey's test at $5 \%$ probability $(\mathrm{p}<0.05)$. 
Table 4. Chemical characterization during storage time.

\begin{tabular}{|c|c|c|c|c|c|}
\hline \multirow{2}{*}{ Treatments } & \multirow{2}{*}{ Parameters } & \multicolumn{4}{|c|}{ Storage time (days) } \\
\hline & & 01 & 30 & 60 & 90 \\
\hline \multirow{3}{*}{ TC } & Moisture (g/100 g) & $24.23 \pm 1.07^{\mathrm{b}}$ & $31.12 \pm 2.06^{\mathrm{a}}$ & $28.37 \pm 1.10^{\mathrm{ab}}$ & $29.49^{\mathrm{ab}} \pm 0.43^{\mathrm{ab}}$ \\
\hline & $\mathrm{pH}$ & $6.10 \pm 0.07^{\mathrm{a}}$ & $5.43 \pm 0.02^{\mathrm{b}}$ & $5.44 \pm 0.05^{\mathrm{b}}$ & $5.13^{\mathrm{b}} \pm 0.25^{\mathrm{b}}$ \\
\hline & TTA (g/100 g) & $2.75 \pm 0.14^{\mathrm{ab}}$ & $1.88 \pm 0.01^{\mathrm{b}}$ & $3.29 \pm 0.66^{\mathrm{a}}$ & $1.79^{\mathrm{b}} \pm 0.13^{\mathrm{b}}$ \\
\hline \multirow{3}{*}{$\mathrm{T} 5$} & Moisture (g/100 g) & $28.31 \pm 0.25^{\mathrm{a}}$ & $26.06 \pm 0.40^{\mathrm{b}}$ & $24.01 \pm 0.25^{c}$ & $24.83 \pm 0.55^{c}$ \\
\hline & $\mathrm{pH}$ & $5.94 \pm 0.06^{\mathrm{a}}$ & $5.56 \pm 0.06^{\mathrm{b}}$ & $5.38 \pm 0.04^{\mathrm{b}}$ & $5.52 \pm 0.11^{\mathrm{b}}$ \\
\hline & TTA (g/100 g) & $2.46 \pm 0.27^{\mathrm{ab}}$ & $1.41 \pm 0.14^{\mathrm{c}}$ & $3.02 \pm 0.27^{\mathrm{a}}$ & $1.88 \pm 0.01^{\mathrm{bc}}$ \\
\hline \multirow{3}{*}{$\mathrm{T} 7$} & Moisture (g/100 g) & $28.57 \pm 0.57^{\mathrm{a}}$ & $29.34 \pm 0.29^{\mathrm{a}}$ & $26.93 \pm 0.76^{\mathrm{a}}$ & $27.39 \pm 1.90^{\mathrm{a}}$ \\
\hline & $\mathrm{pH}$ & $5.84 \pm 0.01^{\mathrm{a}}$ & $5.58 \pm 0.02^{\mathrm{b}}$ & $5.52 \pm 0.01^{\mathrm{bc}}$ & $5.50 \pm 0.03^{c}$ \\
\hline & TTA (g/100 g) & $2.65 \pm 0.27^{\mathrm{a}}$ & $1.23 \pm 0.13^{\mathrm{b}}$ & $2.74 \pm 0.14^{\mathrm{a}}$ & $1.79 \pm 0.13^{\mathrm{b}}$ \\
\hline
\end{tabular}

$\mathrm{TC}=$ control sample (without chia); T5 = sample with $5.0 \mathrm{~g} / 100 \mathrm{~g}$ of chia seeds; T7 = sample with $7.5 \mathrm{~g} / 100 \mathrm{~g}$ of chia seeds; TTA = Total Titratable Acidity; Results expressed are as the means \pm standard deviation. Same letters in the same line indicate the values do not differ by Tukey's test at $5 \%$ probability $(\mathrm{p}<0.05)$.

Table 5. Sensory analysis during storage time.

\begin{tabular}{|c|c|c|c|c|c|}
\hline \multirow{2}{*}{ Treatments } & \multirow{2}{*}{ Attributes } & \multicolumn{4}{|c|}{ Storage time (days) } \\
\hline & & 01 & 30 & 60 & 90 \\
\hline \multirow{4}{*}{ T5 } & Colour & $6.56 \pm 1.83^{\mathrm{a}}$ & $5.87 \pm 1.91^{\mathrm{a}}$ & $6.31 \pm 1.60^{\mathrm{a}}$ & $5.65 \pm 1.65^{\mathrm{a}}$ \\
\hline & Aroma & $7.12 \pm 1.73^{\mathrm{a}}$ & $7.26 \pm 1.46^{\mathrm{a}}$ & $7.24 \pm 1.32^{\mathrm{a}}$ & $7.00 \pm 1.77^{\mathrm{a}}$ \\
\hline & Flavour & $7.43 \pm 1.76^{\mathrm{a}}$ & $8.00 \pm 1.48^{\mathrm{a}}$ & $7.58 \pm 1.00^{\mathrm{a}}$ & $7.87 \pm 1.65^{\mathrm{a}}$ \\
\hline & Texture & $7.56 \pm 1.61^{\mathrm{ab}}$ & $7.95 \pm 1.20^{\mathrm{a}}$ & $6.85 \pm 1.74^{\mathrm{b}}$ & $7.56 \pm 1.82^{\mathrm{ab}}$ \\
\hline \multirow{4}{*}{$\mathbf{T 7}$} & Colour & $6.60 \pm 1.93^{\mathrm{a}}$ & $5.41 \pm 2.11^{\mathrm{b}}$ & $6.24 \pm 1.87^{\mathrm{ab}}$ & $5.26 \pm 1.67^{\mathrm{b}}$ \\
\hline & Aroma & $7.29 \pm 1.99^{\mathrm{a}}$ & $6.65 \pm 1.49^{\mathrm{a}}$ & $7.09 \pm 1.74^{\mathrm{a}}$ & $6.90 \pm 1.67^{\mathrm{a}}$ \\
\hline & Flavour & $7.63 \pm 1.89^{\mathrm{a}}$ & $7.78 \pm 1.25^{\mathrm{a}}$ & $7.75 \pm 1.26^{\mathrm{a}}$ & $7.58 \pm 1.66^{\mathrm{a}}$ \\
\hline & Texture & $7.31 \pm 2.08^{\mathrm{a}}$ & $7.85 \pm 1.06^{\mathrm{a}}$ & $7.36 \pm 1.80^{\mathrm{a}}$ & $7.36 \pm 1.89^{\mathrm{a}}$ \\
\hline
\end{tabular}

T5 = sample with $5.0 \mathrm{~g} / 100 \mathrm{~g}$ of chia seeds; T7 = sample with $7.5 \mathrm{~g} / 100 \mathrm{~g}$ of chia seeds; Number of judges in each analysis: 40 ; The results are expressed as the means \pm standard deviation. Same letters in the same line indicate the values do not differ by Tukey’s test at $5 \%$ probability $(\mathrm{p}<0.05)$.

The acceptance of the texture attribute of the T5 sample also oscillated during storage (Table 5). This result may be related to the lower amount of chia present in the T5 sample, which give it a lower lipid content which reduce its softness. According to Pereira et al. (2004) [2], fat acts as a molecular lubricant in cheese breads, giving the bread a greater extensibility, which contributes to a greater elasticity and better crumb texture. In addition, oscillation in texture acceptance may have been influenced by long-term storage. As mentioned by Phimolsiripol et al. (2008) [31], several factors including loss of moisture during storage contribute to the fact that the loaves have a firmer texture than those that were not stored for long periods.

\section{Conclusion}

Although its colour attribute exhibited negative oscillations during storage, the $7.5 \mathrm{~g} / 100 \mathrm{~g}$ chia seed sample maintained physical stability. In addition, the consumption of cheese loaves (2 servings, $100 \mathrm{~g}$ ) containing this concentration of the seed can contribute $50 \%$ of the daily recommended intake of alpha linolenic acid. Therefore, the cheese bread formulation with 7.5 g/100 g chia presented satisfactory physico-chemically and sensorially characteristics. In addition, the product presented itself as an excellent source of $\omega-3$ fatty acids. Further studies are needed to evaluate the fatty acid profile, lipid stability and microbiological qualities during storage of bakery products.

\section{Acknowledgements}

We are grateful to Vila Ervas ${ }^{\circledR}$ Vila Velha/ES (Brazil) for the donation of chia seeds, the Federal University of Espírito Santo (Brazil) for the infrastructure of laboratories and reagents assigned, and Ana Vládia Bandeira Moreira, Professor of the Department of Nutrition of the Federal University of Viçosa (Brazil) for the analysis of fatty acids.

\section{Statement of Competing Interests}

We affirm that the manuscript has not been previously published, is not currently submitted for review to any other journal and will not be submitted elsewhere before a decision is made.

There is no conflict of interest for the authors listed above. 


\section{References}

[1] Oliveira, M.B.B. and Moraes, P.C.B.T. "Elaboration and acceptability of cheese bread enriched with omega-3”, Boletim do Centro de Pesquisa de Processamento de Alimentos, 27(2), 231-240. 2009.

[2] Pereira, J., Ciacco, C.F., Vilela, E.R. and Pereira, R.G.F. "Function of the ingredients in the consistency of the dough and in the characterics of the cheese breads", Food Science and Technology, 24(4), 494-500. 2004.

[3] Borneo, R., Aguirre, A. and León, A.E. "Chia (Salvia hispânica L.) gel can be used as egg or oil replacer in cake formulations", Journal of the American Dietetic Association, 110(6), 946-949. 2010.

[4] Martínez, M.L., Marín, M.A., Faller, C.M.S., Revol, J., Penci, M.C. and Ribotta, P.D. "Chia (Salvia hispanica L.) oil extraction: Study of processing parameters”, LWT-Food Science and Technology, 47(1). 78-82. 2012.

[5] Coelho, M.S. and Salas-Mellado, M.M. "Review: Chemical composition, functional properties and technological applications of chia (Salvia hispanica L.) seeds in foods”, Brazilian Journal of Food Technology, 17(4), 259-268. 2014.

[6] Marineli, R.S., Moraes, É.A., Lenquiste, S.A., Godoy, A.T., Eberlin, M.N. and Jr, M. R. M. "Chemical characterization and antioxidant potential of Chilean chia seeds and oil (Salvia hispanica L.)”, LWT-Food Science and Technology, 59(2), 13041310. 2014.

[7] Santos, R.D., Gagliardi, A.C.M., Xavier, H.T., Magnoni, C.D., Cassani, R., Lottenberg, A.M.P., Casella Filho, A., Araújo, D.B., Cesena, F.Y., Alves, R.J., Fenelon, G., Nishioka, S.A.D., Faludi, A.A., Geloneze, B., Scherr, C., Kovacs, C., Tomazzela, C., Carla, C., Barrera-Arellano, D., Cintra, D., Quintão, E., Nakandakare, E.R., Fonseca, F.A.H., Pimentel, I., Santos, J.E., Bertolami, M.C., Rogero, M., Izar, M.C., Nakasato, M., Damasceno, N.R.T., Maranhão, R., Cassani, R.S.L., Perim, R. and Ramos, S. "I Diretriz sobre o consumo de gorduras e saúde cardiovascular”, Arquivos Brasileiros de Cardiologia, 100(1), 01-40. 2013.

[8] Marineli, R.D.S., Lenquiste, S.A., Moraes, É.A. and Jr, M.R.M. "Antioxidant potential of dietary chia seed and oil (Salvia hispanica L.) in diet-induced obese rats”, Food Research International, 76(3), 666-674. 2015.

[9] Sacks, F.M., Lichtenstein, A.H., Wu, J.H.Y, Appel, L.J., Creager, M.A., Kris-Etherton, P.M., Miller, M., Rimm, E.B., Rudel, L.L., Robinson, J.G., Stone, N.J. and Horn, L.V.V. "Dietary fats and cardiovascular disease: A presidential advisory from the American Heart Association”, Circulation, 136(3), 01-23. 2015.

[10] Conforti, F.D. and Davis, S.F. "The effect of soya flour and flaxseed as a partial replacement for bread flour in yeast bread", International Journal of Food Science and Technology, 41(2), 95-101. 2006.

[11] Drusch, S. and Mannino, S. "Patent-based review on industrial approaches for the microencapsulation of oils rich in polyunsaturated fatty acids", Trends in Food Science \& Technology, 20(6-7). 237-244. 2009.

[12] Pereira, P.A.P., Ramos, T.M., Gajo, A.A. and Gomes, U.J. "Viability of using ricotta in preparation of cheese bread", Ciência Rural, 40(11), 2356-2360. 2010.

[13] Pizzinatto, A., Magno, C.P.R.S., Campagnollli, D.M. F., Vitti, P. and Leitão, R.F.F. Avaliação tecnológica de produtos derivados de farinha de trigo (pão, macarrão, biscoito) (3th ed.). ITAL. 1993.

[14] Minim, V.P.R. Análise sensorial: estudo com consumidores. (3th ed.). Editora UFV. 2013.

[15] AOAC - Association of Official Analytical Chemists. Official methods of analyses of the Association of Analytical Chemists (18th ed.), 2005.

[16] Wilson, E.D., Santos, A.C. and Vieira, E.C. Energia. In Dutra-DeOliveira, J.E., Santos, A.C. and Wilson, E.D (Eds.), Nutrição básica. Sarvier. 1982.
[17] Folch, J., Lees, M. and Sloane-Staniley, G.H. “A simple method for the isolation and purification of total lipides from animal tissues”, Journal of Biological Chemistry, 226(1), 497-509. 1957.

[18] Hartman, L. and Lago, B.C.A. "Rapid preparation of fatty acid methyl esters from lipids” Laboratory Practice, 22. 475-477. 1973

[19] Barra, P.M.C., Marcone, A.L.O., Nery-Enes, B., Cardoso, L.M., Cesário, C.C., Moreira, A.V.B., Pinheiro-Sant'Ana, H.M. and Peluzio, M.C.G. "Simultaneous analysis of saturated and unsaturated fatty acids present in pequi fruits by capillary electrophoresis”, Química Nova, 36(9). 1430-1433. 2013.

[20] Silva, M.R., Garcia, G.K.S. and Ferreira, H.F. "Physical, chemical characteristics and acceptability of low-calorie cheese bread", Alimentos e Nutrição, 14(1), 69-75. 2003.

[21] Zenebon, O., Pascuet, N.S. and Tiglea, P. Sensory analysis. In Zenebon, O., Pascuet, N. S. and Tiglea, P. (Eds.). Physicochemical methods for food analysis. Instituto Adolfo Lutz. 2008.

[22] Katina, K., Salmenkallio-Marttila, M., Partenen, R., Forssell, P. and Autio, K. "Effects of sourdough and enzymes on staling of high-fi bre wheat bread", LWT-Food Science and Technology, 39(5), 479-491. 2006

[23] Aplevicz, K.S. and Demiate, I.M. "Physicochemical analyses of commercial samples of cheese bread premix and production of cheese breads with addition of okara”, Ciência e Agrotecnologia, 31(5). 1416-1422. 2007.

[24] Costa, A., Barauna, A.C., Bertin, R.L. and Tavares, L.B.B. "Flaxseed flour addition on fatty acid profile and sensory properties of brazilian cheese roll”, Ciência e Agrotecnologia, 36(4), 431-438. 2012

[25] Capitani, M.I., Corzo-Rios, L.J., Chel-Guerrero, L.A., BetancurAncona, D.A., Nolasco, S.M. and Tomas, M.C. "Rheological properties of aqueous dispersions of chia (Salvia hispanica L.) mucilage”, Journal of Food Engineering, 149, 70-77. 2015.

[26] Pereira, B.S., Pereira, B.S., Cardoso, E.S., Mendonça, J.O.B., Souza, L.B., Santos, M.P., Zago, L. and Freitas, S.M.L. "Physical, chemical and sensory analysis of gluten-free potato bread enriched with chia flour”, Demetra: Alimentação, Nutrição \& Saúde, 8(2): 125-136. 2013.

[27] Fellows, P.J. Tecnologia do processamento de alimentos: princípios e práticas (2th ed.). Editora Artmed. 2006.

[28] World Health Organization. "Interim summary of conclusions and dietary recommendations on total fat \& fatty acids”, From the Joint FAO/WHO Expert Consultation on Fats and Fatty Acids in Human Nutrition. 2008. Available: http://www.who.int/nutrition/topics/FFA_summary_rec_conclusio n.pdf [Accessed Sep. 2, 2017]

[29] Philippi, S.T. (2014). Pirâmide dos alimentos - Fundamentos básicos da nutrição. (2th ed.). Manole. 2014.

[30] Stoll, L., Flores, S.H. and Thys, R. C. S. "Citrus peel fiber and its application as a fat substitute in loaf brad”, Ciência Rural, 45(3), 567-573. 2015.

[31] Verdú, S., Vásquez, F., Ivorra, E., Sánchez, A.J., Barat, J.M. and Grau, R. "Physicochemical effects of chia (Salvia hispanica) seed flour on each wheat bread-making process phase and product storage”, Journal of Cereal Science, 65, 67-73. 2015.

[32] Phimolsiripol, Y., Siripatrawan, U., Tulyathan, V. and Cleland, D.J. "Effects of freezing and temperature fluctuations during frozen storage on frozen dough and bread quality", Journal of Food Engineering, 84, 48-56. 2008.

[33] Silva, R.P.G., Pereira, J., Nery, F.C. and Vilela, E. R. "Effect of freezing on the physical and chemical characteristics of cheese bread”, Ciência e Agrotecnologia, 33(1), 207-212. 2009.

[34] Moraes, É.A., Dantas, M.I.S., Morais, D.C., Silva, C.O., Castro, F.A.F., Martino, H.S.D. and Ribeiro, S.M.R. "Sensory evaluation and nutritional value of cakes prepared with whole flaxseed flour", Food Science and Technology, 30(4), 974-979. 2010. 